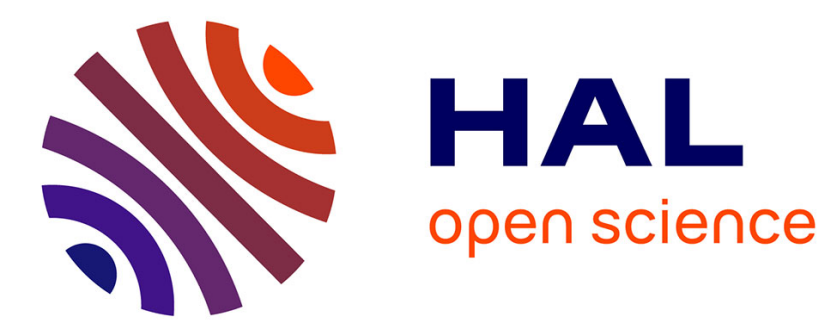

\title{
Du système mercantile à l'ordre diplomatique : les ambassades entre Égypte mamlūke et Yémen rasūlide (VIIe-IXe/XIIIe-XVe siècle) \\ Eric Vallet
}

\section{- To cite this version:}

Eric Vallet. Du système mercantile à l'ordre diplomatique: les ambassades entre Égypte mamlūke et Yémen rasūlide (VIIe-IXe/XIIIe-XVe siècle). Les relations diplomatiques au Moyen Âge. Sources, pratiques, enjeux, Jun 2010, Lyon, France. p. 269-301. hal-00638712

\section{HAL Id: hal-00638712}

https://hal-paris1.archives-ouvertes.fr/hal-00638712

Submitted on 7 Nov 2011

HAL is a multi-disciplinary open access archive for the deposit and dissemination of scientific research documents, whether they are published or not. The documents may come from teaching and research institutions in France or abroad, or from public or private research centers.
L'archive ouverte pluridisciplinaire HAL, est destinée au dépôt et à la diffusion de documents scientifiques de niveau recherche, publiés ou non, émanant des établissements d'enseignement et de recherche français ou étrangers, des laboratoires publics ou privés. 


\section{Du système mercantile à l'ordre diplomatique : les ambassades entre Égypte mamlūke et Yémen rasūlide $\left(\mathrm{VII}^{\mathrm{e}}-\mathrm{IX}^{\mathrm{e}} / \mathbf{X I I I} \mathrm{e}^{\mathrm{e}}-\mathrm{XV}^{\mathrm{e}} \text { siècle }\right)^{*}$}

Version avant publication d'un article paru dans Les relations diplomatiques au Moyen Âge. Formes et enjeux, XLIe congrès de la SHMESP, Paris, Publications de la Sorbonne, 2011, p. 269-301.

Parvenu au pouvoir en 725/1325 le sultan de l'Inde, Muhammad ibn Tugiluq était sans aucun doute, en cette première moitié de $\mathrm{VIII}^{\mathrm{e}} / \mathrm{XIV}^{\mathrm{e}}$ siècle, l'un des plus puissants souverains du monde connu. Héritier du pouvoir des sultans de Delhi, il avait parachevé l'œuvre de conquête du sous-continent indien lancée par 'Alā' al-Dīn Halğī sous l'étendard de l'Islam à la fin du VII $/ \mathrm{XIII}^{\mathrm{e}}$ siècle $^{1}$, devenant ainsi, aux dires mêmes de plusieurs de ses contemporains lettrés, un «second Alexandre $»^{2}$. Une fois parvenu au faîte de son règne, c'est assez naturellement qu'il se tourna vers Le Caire où avait été accueilli en 659/1261 l'un des membres de la famille abbasside rescapé du massacre perpétré par les Mongols en 656/1258 ${ }^{3}$. Le calife abbasside du Caire était certes dépouillé de toute autorité réelle, mais obtenir de lui un diplôme officiel d'investiture ne pouvait pas déplaire au sultan de Delhi, en quête d'une légitimité islamique de bon aloi. L'envoyé de Muhammad b. Tuġluq était chargé d'un riche présent destiné aux autorités du Caire, au premier chef desquelles se trouvait le sultan al-Nāṣir Muhammad b. Qalāwūn ${ }^{4}$.

L'ambassadeur quitta l'Inde en route vers l'ouest, au cours de l'année 729/1329, profitant des vents favorables qui le poussaient le long des côtes de la péninsule arabique. Parvenu au port d'Aden, à l'extrême sud du Yémen, son navire fit relâche, comme cela était coutumier pour qui désirait passer de l'océan Indien en mer Rouge. Protégé par un site naturel exceptionnel et par un système de fortifications très élaboré, la cité d'Aden se présentait comme une véritable sentinelle, verrouillant l'entrée de la mer Rouge depuis l'océan Indien ${ }^{5}$. C'est pourtant dans cette place jouissant d'une excellente réputation de sûreté que le voyage de l'envoyé du sultan de Delhi prit brutalement fin. Des mamlūks, soldats esclaves affranchis, appartenant au sultan du Yémen, l'assassinèrent de nuit dans des circonstances obscures. Les sources égyptiennes - les seules à évoquer l'événement - ne permettent pas de savoir ce qui

\footnotetext{
* Par convention, nous donnons systématiquement la date dans le calendrier hégirien, suivie de la date dans le calendrier grégorien. Le système de translittération de l'arabe suit celui de la revue Arabica.

${ }^{1}$ Sur le règne de Muhammad ibn Țugluq, voir la synthèse récente de P. JACKSON, The Delhi Sultanate. $A$ Political and Military History, Cambridge, 1999.

${ }^{2}$ IBN FADL ALLĀH AL-'UMARI, al-Ta 'rîf bi l-muștalaḥ al-šarî̄f, Le Caire, 1312 H., p. 48.

${ }^{3}$ Sur l'installation du califat au Caire, l'étude classique de D. Ayalon (« Studies on the Transfer of the 'Abbasid Caliphate », Arabica, 1960) sera utilement complété par P. M. HolT, «Some Observations on the Abbasid Caliphate of Cairo », BSOAS, 47 (1984), en part. p. 501-503, et S. HeIDEMANN, Das Aleppiner Kalifat (A.D. 1261). Vom Untergang des Kalifates in Bagdad über Aleppo zu den Restaurationen in Kairo, Leyde, 1994.

${ }^{4}$ Fils du sultan al-Manșūr Qalāwūn (1270-1280), al-Nāṣir Muhammad fut démis à deux reprises du pouvoir (entre 1294 et 1298, et 1310 et 1311) avant d'établir fermement son pouvoir au cours de son long troisième règne (1311-1341). Voir A. LeVAnONI, A Turning Point in Mamluk History. The Third Reign of al-Nāṣir Muhammad ibn Qalāwūn (1310-1341), Leyde, 1995.

${ }^{5}$ Sur le rôle d’Aden sous les Rasūlides du Yémen, voir É. VALLET, L'Arabie marchande. État et commerce sous les sultans rasūlides du Yémen (626-858/1229-1454), Paris, 2010, en part. les chap. 2 et 3.

[Texte]
} 
s'est réellement passé à Aden ${ }^{6}$. S'agit-il d'une simple querelle ayant mal tourné, comme l'affirme al-Șafadī ? A-t-on affaire à un crime crapuleux ou à dessein prémédité, encouragé par l'État yéménite lui-même, comme le prétendait le secrétaire de la chancellerie égyptienne Ibn Faḍl Allāh al-'Umarī ? Dans une lettre rédigée en 730/1330 par les soins de ce dernier, le sultan du Caire n'hésite toutefois pas à accuser le jeune sultan du Yémen, al-Muğāhid 'Alī, de s'être comporté en bandit de grand chemin (min qutta $\bar{a}^{\cdot}$ al-tarīq $)^{7}$. Quoi qu'il en soit de ces divergences sur l'auteur des faits, le résultat ne faisait aucun doute : le fastueux présent indien avait été confisqué par les Yéménites, l'ambassade du sultan de Delhi avait bel et bien échoué et l'envoyé n'avait pas franchi le détroit de Bāb al-Mandab, jalousement gardé depuis le Yémen.

Cet épisode n'aurait pas retenu notre attention s'il ne s'inscrivait dans une série d'incidents diplomatiques d'un ordre similaire survenus depuis le milieu du $\mathrm{VII}^{\mathrm{e}} / \mathrm{XIII}^{\mathrm{e}}$ siècle. En 682/1280, les envoyés de prince de Ceylan avaient dû contourner Aden pour se rendre au Caire, par méfiance vis-à-vis du pouvoir régnant sur le Yémen ${ }^{8}$. Quelques années auparavant, le négus éthiopien, dont les ambassadeurs avaient eu des démêlés à Aden, s'était retrouvé contraint de passer par l'intermédiaire du sultan du Yémen pour correspondre avec le souverain du Caire ${ }^{9}$. Cette promotion du pouvoir sultanien yéménite comme intermédiaire obligé entre les pouvoirs riverains de l'océan Indien et l'Égypte, nouveau centre de l'Islam méditerranéen, correspond en réalité à l'avènement d'un véritable « ordre diplomatique » nouveau en mer Rouge dans la seconde moitié du VII $/$ XIII ${ }^{\mathrm{e}}$ siècle, reposant sur la relation privilégiée qui unissait le sultanat du Yémen, entre les mains de la famille des Rasūlides, et celui du Caire, alors contrôlé par les puissants Mamlūks.

Depuis le $\mathrm{V}^{\mathrm{e}} / \mathrm{XI}^{\mathrm{e}}$ siècle, le port d'Aden et ses maîtres successifs avaient entretenu des relations étroites avec l'Égypte. Comme l'a bien montré Jean-Claude Garcin dans sa thèse magistrale sur l'histoire de Qūṣ, la mer Rouge connut alors un essor important de ses activités de commerce et de navigation ${ }^{10}$. Outre les traversées des pèlerins entre le port égyptien de 'Ayḍāb et Ğidda qui s'intensifièrent au cours du V $\mathrm{V}^{\mathrm{e}} / \mathrm{XI}^{\mathrm{e}}$ siècle, c'est aussi à cette époque qu'apparaît dans les sources cette saison de navigation et de commerce désignée sous le nom de Kārim. Cette saison marchande donna, à partir du VII $/$ XIII siècle au moins, son nom aux négociants qui fréquentaient assidûment cette route reliant Aden et 'Aydhāb, connus comme marchands du Kārim ou Kārimis ${ }^{11}$. À partir du V $\mathrm{V}^{\mathrm{e}} / \mathrm{XI}^{\mathrm{e}}$ siècle, le commerce entre l'Égypte et

\footnotetext{
${ }^{6}$ IBN ḤִĞAR AL-'ASQALĀNī, Al-durar al-kāmina fì a 'yānn al-mi’a al-tāmina, éd. S. AL-KARNUKI, Hayderabad, III, p. 460-461; AL-MAQRIZI, Kitāb al-sulūk li-ma 'rifat al-mulūk, éd. M. M. ZIYADA, Le Caire, 1958, II, 2, p. 322 ; AL-ȘAFADI, A ‘yān al- 'aṣr wa-a ‘wān al-naṣr, éd. 'A. ABU ZAYD et al., Damas-Beyrouth, 1998, IV, p. $482-483$.

${ }^{7}$ IBN FAḌL ALLĀH AL-'UMARI, al-Ta 'rīf..., op. cit. n. 2, p. 48-49; AL-QALQASANDI, Șubḥ al-a ‘šă’’ fì șinā'at alinšā', éd. M. ‘A. IBRĀHĪM, Le Caire, 1913-1920, VII, p. 372-373.

${ }^{8}$ Sur cet épisode, voir en part. BAYBARS AL-MANȘŪRĪ, Zubdat al-fikra fì ta'rīh al-hiğra, éd. D. S. RICHARDS, p. 235, et IBN AL-FURAT, Ta'rīh al-duwal wa-l-mulūk, éd. ZURAYQ, Beyrouth, 1942, VII, p. 260, qui présentent deux versions légèrement différentes. La version de Baybars est abrégée par IBN FAḌL ALLĀH AL-'UMARI, Masālik al-abșār fì mamālik al-amșār, Abū Zabī, Markaz Zayd li-l-turāt wa-l-ta'rīhn, I, p. 133 ; AL-MAQRIZI, Kitāb al-sulūk..., op. cit. n. 6, I, p. 713 ; AL-QALQASANDI, Subḥ al-a ‘šā'..., op. cit. n. 7, II, p. 77.

${ }^{9}$ IBN AL-FURĀT, Ta'rīh al-duwal..., op. cit. n. 8, VII, p. 1 et 23-24.

${ }^{10}$ J.-Cl. GARCIN, Un centre musulman de la Haute-Égypte médiévale : Qūs, Le Caire, 1976, p. 101-102.

${ }^{11}$ VALLET, L'Arabie marchande..., op. cit. n. 5, p. 505.
} 
l'Arabie du Sud bénéficia de conditions de transport et d'échange qui devaient rester stables jusqu'au $\mathrm{IX}^{\mathrm{e}} / \mathrm{XV}^{\mathrm{e}}$ siècle.

La conquête ayyūbide du Yémen à partir de 569/1173 par le frère de Saladin contribua à renforcer plus encore ces liens d'un point de vue politique. La majeure partie du bassin de la mer Rouge se soumit alors à l'autorité d'une même famille, depuis l'Égypte jusqu'aux rivages du Yémen, en passant par le Hiğāz et La Mekke ${ }^{12}$. Dès la fin des années 620/1220, cette relation privilégiée fut néanmoins rompue avec l'installation du pouvoir rasūlide au sud de l'Arabie, fondé par al-Manșūr 'Umar b. 'Alī b. Rasūl, un ancien lieutenant turcoman du sultan ayyūbide du Yémen qui fit reconnaître son pouvoir indépendant par le calife de Bagdad dès 632/1235. L'unité politique du bassin de la mer Rouge avait été de courte durée.

Pour le nouveau souverain du Yémen, le contrôle de la mer Rouge représentait un enjeu crucial face à ses anciens maîtres. Dès les années 630/1230, al-Manșūr 'Umar s'empara de La Mekke et anéantit le potentiel naval ayyūbide en mer Rouge ${ }^{13}$. La circulation des gros navires de commerce, de leurs passagers et de leurs riches cargaisons passa alors sous le contrôle du pouvoir yéménite qui mit en place, au plus tard dans la seconde moitié du VII $/ \mathrm{XIII}^{\mathrm{e}}$ siècle, une flotte marchande d'État assurant le gros des liaisons avec l'Égypte. Pendant près de deux siècles, le commerce des marchands du Kārim prospéra à l'ombre de l'État rasūlide, selon une organisation désormais mieux connue grâce à la découverte récente d'archives du port d'Aden ${ }^{14}$.

L'État mamlûk, fermement établi en Égypte et en Syrie à partir de 658/1260, ne put rien contre cet état de fait. Malgré quelques tentatives, il ne fut pas en mesure de reconstituer à son profit l'unité du bassin de la mer Rouge et dut s'accommoder de la présence de ce pouvoir sultanien indépendant sur son flanc sud-est ${ }^{15}$. Le meurtre de l'ambassadeur du sultan de Delhi en 730/1330 ne devait être perçu autrement que comme un rappel et un avertissement: l'État rasūlide ne pouvait voir que d'un mauvais œil l'établissement de relations directes entre l'Égypte mamlūke et l'Inde islamique qui représentait une menace directe contre ses intérêts en mer Rouge et dans l'océan Indien. Le voyage de l'envoyé de Delhi constituait une infraction à l'équilibre des puissances né du contexte de la seconde moitié du VII $/ \mathrm{XIII}^{\mathrm{e}}$ siècle, lorsque Mamlūks et Rasūlides étaient parvenus à s'entendre sur une reconnaissance mutuelle, voire sur une forme d'alliance placée sous le signe du combat commun pour le bien de l'Islam, où chacun revendiquait une place de choix. Jusqu'aux années $820 / 1420$, période où le sultanat rasūlide sombra dans l'anarchie avant de s'effacer définitivement en 858/1454, les deux puissances riveraines de la mer Rouge ont ainsi été unies par un ensemble de relations diplomatiques régulières, aux formes stables et codifiées, effectives sur la longue durée, bref par un véritable « ordre diplomatique ».

L'échange d'ambassades entre Ta'izz, capitale des Rasūlides, et Le Caire, siège du sultanat mamlūk, est sans aucun doute ce qui exprime le mieux l'existence de cet ordre stable. Leur recensement dans les sources syro-égyptiennes et rasūlides du VII $/ \mathrm{XIII}^{\mathrm{e}}$ au IX $\mathrm{X}^{\mathrm{e}} / \mathrm{XV}^{\mathrm{e}}$ siècle révèle à quel point celles-ci se sont rapidement structurées en un rituel régulièrement

\footnotetext{
${ }^{12}$ Voir en particulier à ce sujet M. L. BATES, Yemen and its Conquest by the Ayyubids of Egypt (AD 1137-1202), Ph.D., Univ. de Chicago, 1975.

${ }^{13}$ AL-ĞANADI, Al-sulūk fi tabaqāt al- ‘ulamā’ wa-l-mulūk, éd. M. AL-AKWA', Șan'ā’, 1989, II, p. 541.

${ }^{14}$ VALLET, L'Arabie marchande..., op. cit. n. 5, p. 482-493.

${ }^{15}$ Sur les expéditions mamlūkes avortées en mer Rouge de 692/1293 et 705-707/1306-1308 : ibid., p. 498-501.
} 
renouvelé. Entre 661/1263 et 829/1426, trente-cinq ambassades au moins sont attestées, certaines brièvement, d'autres avec force détails. Elles peuvent être regroupées en deux phases principales, séparées par une interruption majeure entre 730/1330 et 752/1353, à la suite du meurtre de l'ambassadeur indien ${ }^{16}$. Ce relevé systématique - l'exhaustivité étant, en la matière, impossible à atteindre - n'échappe pas au biais des sources : il ne donne qu'une image incomplète de l'intensité des échanges, d'autant que Ta'izz ou Le Caire n'étaient pas les seuls terrains sur lesquels les représentants du pouvoir yéménite et mamlūk se rencontraient. La Mekke était un autre théâtre annuel, tout aussi important, de ce face-à-face entre les deux États sultaniens. Il n'en sera cependant pas question ici, tant le cadre de la Ville sainte de l'Islam imposait ses enjeux propres ${ }^{17}$. Dans les moments d'échange le plus intense, il semble bien en effet que les ambassades se soient succédées selon une rotation quasi ininterrompue, une ambassade repartant l'année suivant le retour de la précédente. Cette circulation très régulière de délégations, au fondement même de l' "ordre diplomatique » mamlūko-rasūlide, fut érigée en principe connu de tous comme l'atteste Ibn 'Abd al-Mağ̄ìd, secrétaire de la chancellerie yéménite dans les années 710-720/1310-1320 : "L'envoi des présents de cette sorte ne devait pas être retardé au-delà de deux ou trois ans; il était en effet nécessaire pour affirmer l'affection et l'amitié (al-mawadda wa-l-mahabba), ainsi que la perpétuation du compagnonnage (suhba) qui avait été conclu ${ }^{18} »$. L'échange d'ambassades se fait ainsi véritable « coutume » ('āda), un terme qui apparaît à plusieurs reprises pour qualifier ce que nous désignons comme ordre diplomatique ${ }^{19}$. Il ne faut donc pas négliger l'installation d'un effet de routine qui explique que de nombreuses ambassades " ordinaires » n'ont sans aucun doute pas été signalées dans les sources.

Comme pour tout ce qui a trait aux rituels du pouvoir, la consignation par écrit de ces ambassades dans des sources narratives bien informées et souvent proches des milieux de chancellerie obéit à des règles d'écriture qui peuvent être assez facilement décomposées. L'ambassade se présente comme un ensemble d'actes codifiés, se succédant dans le temps : accueil des ambassadeurs (et protection éventuelle lors de la traversée du territoire), liste sommaire ou détaillée du contenu du présent, identité et qualité des envoyés, déroulement de l'audience du souverain, évocation de la lettre diplomatique, contre-présent envoyé en retour par la puissance accueillante. Tous ces registres ne sont toutefois pas mentionnés de façon systématique. Au cœur du rituel diplomatique se trouve sans conteste le cadeau ou présent (hadiyya) envoyé par le souverain, à tel point que dans quelques occurrences ce cadeau sert à désigner par métonymie l'ensemble de l'ambassade ${ }^{20}$. Autour du présent, il est aussi fait

\footnotetext{
${ }^{16}$ Nous avons regroupé en annexe l'inventaire détaillé de ces 35 ambassades d'après les sources arabes éditées et la traduction des principaux passages les concernant. Pour l'histoire événementielle des relations mamlūkorasūlides : ibid., notam. p. 494-505.

${ }^{17}$ Ibid., p. 439-440, 456-458, 468-469, 635-649.

${ }^{18}$ IBN 'ABD AL-MAGID, Bahğat al-zaman fì ta’rīh̆ al-Yaman, éd. 'A. AL-ḤIBŠī et M. AL-SANABĀNĪ, Șan'ā', 1988, p. 235. Sur la portée du lien de șuḥba dans le monde mamlūk, voir M. EYCHENNE, «Le bayt à l'époque mamlouke. Une entité sociale à revisiter », Annales islamologiques, 42 (2008), p. 281-283.

${ }^{19}$ Voir les ambassades II-b, V, VI, VIII, X, XXI, XXXV citées en annexe.

${ }^{20}$ Voir à titre d'exemple les ambassades XXIX ou XXXII en annexe. Sur la place centrale des cadeaux dans la diplomatie mamlūke, voir l'article de M. M. AL-WAQQAD, «Al-Hadāyā wa-l-tuḥaf zaman salāṭīn al-Mamālīk albahriyya, 648-784 h./1250-1382 m. », Hawliyyāt Kulliyyat al-Âdāb (Univ. de 'Ayn Šams), 28 (2000), p. 185240, et F. BAUDEN, « Les relations diplomatiques entre les sultans mamlouks circassiens et les autres pouvoirs du Dār al-islām. L'apport du ms. Ar. 4440 BNF, Paris », Annales Islamologiques, 41 (2007), p. 13.
} 
régulièrement mention de l'audience, et, par ordre de fréquence décroissante, des lettres accompagnant le présent et de l'identité des ambassadeurs. Enfin, des mentions épisodiques se rattachent à des circonstances particulières (protection des émissaires).

Ces ambassades se distinguent ainsi par la publicité qui était donnée aux gestes accompagnant le va-et-vient des délégations diplomatiques. Si les principales sources narratives mamlūkes et rasūlides détaillent avec minutie le contenu des présents échangés de part et d'autre, le contenu politique des missives qui accompagnaient ces ambassades est rarement explicité par ces mêmes sources ${ }^{21}$. L'objet de ces lettres variait en effet d'une ambassade à l'autre : avènement d'un nouveau souverain, annonce d'une victoire militaire, plus rarement demande de soutien ou protestation contre des actions contraires à l'esprit d'entente et de compromis qui régissait les relations mamlūko-rasūlides: toutes ces expressions circonstancielles de l'échange diplomatique, embellies par les fleurs de la rhétorique de chancellerie, s'effaçaient aux yeux de la postérité - c'est-à-dire aux yeux des chroniqueurs - devant la force et l'éclat des gestes posés lors des ambassades.

Outre la mention récurrente du "présent », l'énumération parfois interminable des produits rares et précieux qui le composaient avait en effet l'intérêt majeur de réaffirmer l'existence d'une relation étroite tout en laissant le sens de cette relation dans une ambiguïté soigneusement entretenue par les deux parties. Ainsi, du point de vue mamlūk, le présent envoyé par le sultan rasūlide signifiait l'affirmation de la supériorité égyptienne: se rapprochant d'une forme de tribut, le présent rasūlide valait acte d'allégeance. Le secrétaire de la chancellerie égyptienne et encyclopédiste Ibn Faḍl Allāh al-'Umarī, auteur d'une ample description du monde, comprenant notamment un tableau du royaume du Yémen, ne dit pas autre chose : "Le souverain du Yémen échange des présents (yuhādî) avec le souverain de l'Égypte, car il cherche à l'amadouer en raison de la position [du souverain égyptien] qui le domine (tasallut ) depuis la mer et la terre du Hiğă $z^{22}$. » Produit d'un rapport de force favorable au sultan du Caire, l'envoi du présent rasūlide était aux yeux d'Ibn Faḍl Allāh al'Umarī la manifestation d'une puissance mamlūke réelle mais non formalisée. Il impliquait l'acceptation au moins implicite de la supériorité égyptienne. En revanche, du point de vue du sultan rasūlide, l'échange de présents avait valeur de reconnaissance de son statut égal à celui du sultan mamlūk et de la légitimité de son pouvoir indépendant.

La comparaison des récits de l'échange d'ambassade de 666/1268 constitue un bon exemple de ce jeu d'interprétation fondé sur l'ambivalence des cadeaux échangés. Deux sources contemporaines, indépendantes l'une de l'autre, relatent l'événement à l'intérieur de l'Empire mamlūk. Toutes deux commencent par l'énumération du contenu du présent diplomatique en des termes assez proches, mais l'interprétation qu'elles en donnent est profondément différente. La première (II-a), extraite de la biographie " autorisée » du sultan al-Zāāir Baybars rédigée par son chancelier Ibn 'Abd al-Ẓāhir, reflète le point de vue du premier cercle du pouvoir sur cet échange inaugural. Le présent fastueux envoyé par le maître

\footnotetext{
${ }^{21}$ Le texte des missives n'est qu'exceptionnellement joint au récit de l'ambassade dans les sources narratives (cas de l'ambassade V). Trois autres lettres acheminées lors de ces ambassades ont été préservées dans le manuel de chancellerie du secrétaire égyptien al-Qalqašandī : ambassades VIII et XXVII ; la troisième lettre se rapporte à une ambassade non datée des années 720/1320 (AL-QALQASANDI, Subḥ al-a ‘šă'..., op. cit. n. 7, VII, p. 362365).

${ }^{22}$ IBN FAḍL ALLAH AL-'UMARI, Masālik al-abṣār fì mamālik al-amṣār. L’Égypte, la Syrie, le Hijāz et le Yémen, éd. A. F. SAYYID, Le Caire, p. 155.
} 
du Yémen a pour contrepartie exacte la remise d'une tunique et d'armes que Baybars avaient portées au combat, en signe de cessation de l'hostilité (amān) des Mamlūks vis-à-vis des Rasūlides. Ce geste établit ainsi une relation de compagnonnage (suḥba) entre les deux sultans, valable aussi bien en temps de paix qu'en temps de guerre. La traduction de cette reconnaissance mutuelle dans l'ordre du protocole de chancellerie - le Rasūlide se voit désigné par le titre de "Son altesse auguste et royale le sultan »- est secondaire et n'intervient qu'en conclusion du rituel de l'échange. Tout autre est la présentation du second récit de cette ambassade (II-b), œuvre du savant damascène al-Yūnīnī († 726/1326), beaucoup plus éloigné du monde de la cour. Al-Yūnīnī semble plutôt coucher par écrit l'interprétation qui circulait parmi les élites civiles, religieuses ou militaires du royaume : il était entendu que l'envoyé du sultan rasūlide avait fait acte de soumission formelle, en s'engageant à dire le prêche du vendredi au nom du Mamlūk, et que Baybars l'avait en retour doté d'une investiture en bonne et due forme. Toute prétention rasūlide à exercer un pouvoir souverain (sultāan) était donc niée. Il est intéressant de constater la coexistence des deux discours au sein même de l'Empire mamlūk, comme si cet État, forcé de reconnaître l'indépendance formelle du Rasūlide, s'en était tenu à une position plus réaliste que les élites de l'Empire, attachées à l'idée d'une souveraineté mamlūke s'étendant bien au-delà de son cœur syro-égyptien.

Nombre d'autres exemples plus tardifs pourraient être donnés qui montrent le maintien de ces deux interprétations concurrentes jusqu'au début $\mathrm{du} I \mathrm{IX}^{\mathrm{e}} / \mathrm{XV}^{\mathrm{e}} \operatorname{siècle}^{23}$. Ce paradoxe s'explique assez bien par la disjonction entre les prétentions mamlūkes à s'ériger comme nouvel État impérial, protecteur suprême du Dār al-Islām, et la capacité effective de cet État à se faire reconnaitre comme tel par les pouvoirs qui lui étaient directement voisins. Anne F. Broadbridge a bien montré dans un ouvrage récent comment s'est mise en place cette rhétorique de la "puissance islamique » au cours de la seconde moitié du VII $/ \mathrm{XIII}$ e siècle, dans le contexte de l'affrontement avec les Mongols ${ }^{24}$. Insistons simplement ici sur la manière dont le pouvoir rasūlide a su s'adapter à cette nouvelle rhétorique inaugurée avec le règne de Baybars. D'un côté, le sultan rasūlide réussit sans mal à maintenir son indépendance effective qui se marquait par l'absence de toute mention des sultans et des califes du Caire dans la prière du vendredi et sur les monnaies ${ }^{25}$. De l'autre, il reconnut de façon toute symbolique la supériorité du sultan du Caire dans l'ordre du ğihād par un certain nombre de gestes forts - en faisant nouer son étendard à celui du sultan mamlūk, lors du pèlerinage de La Mekke qui suivit la victoire de 'Ayn Ğalūt, en demandant à Baybars de lui envoyer sa tenue de guerre, ou en envoyant des hommes combattre contre les Francs aux côtés des troupes mamlūkes ${ }^{26}$. Par les ressources symboliques qu'il offrait à chacun des acteurs, l'échange permanent d'ambassades était en réalité la seule façon d'ancrer dans la durée ce qui n'était au départ

\footnotetext{
${ }^{23}$ Voir les ambassades VIII, XVI ou XVII.

${ }^{24}$ A. F. BROADBRIDGE, Kingship and Ideology in the Islamic and Mongol Worlds, Cambridge, 2008, p. $27-62$.

${ }^{25}$ Jusqu'à la chute de la dynastie, c'est le nom du dernier calife 'abbāside de Bagdad, al-Musta'șim bi-llāh, qui fut prononcé à titre posthume dans les huttba du royaume rasūlide (IBN HAGAR, Inbā' al-gumr bi-abnā' al- 'umr fì l-ta'rīh, éd. M. 'A. HAN, Hayderabad, 1967, IV, p. 2).

${ }^{26}$ Voir la place du ğihād dans le récit de l'ambassade II-a, ainsi que la contribution des Rasūlides à la lutte contre les Croisés rapportée par AL-ĞANADI, Al-sulūk..., op. cit. n. 13, II, p. 552, et MARCO POLO, Devisement du monde, éd. et trad. fr. R. KAPPLER, Paris, 2004, p. 205.
} 
qu'un compromis précaire entre deux pouvoirs rivaux, en jouant des symboles du rituel diplomatique, interprétés diversement par les parties en présence ${ }^{27}$.

Au-delà de cet enjeu premier, proprement politique, la nature même des cadeaux envoyés par le sultan rasūlide au sultan mamlūk invite à examiner la question de l'" ordre diplomatique " établi en mer Rouge entre $\mathrm{XIII}^{\mathrm{e}}$ et $\mathrm{XV}^{\mathrm{e}}$ siècle dans ses dimensions proprement économiques. Les produits les plus recherchés du commerce de l'océan Indien - épices et aromates, tissus et bois précieux $-\mathrm{y}$ tenaient une place importante. Le présent signifiait ainsi le partage symbolique de toutes les ressources tirées des négociants qui passaient par le Yémen, traversaient la mer Rouge sous contrôle rasūlide avant de pénétrer sur le territoire égyptien. En offrant à intervalles réguliers un condensé des produits du marché d'Aden aux élites militaires du Caire, les Rasūlides ne cherchaient pas seulement à exhiber leur puissance matérielle et leur prestige, ils offraient tout simplement la preuve de leur capacité à maîtriser les divers réseaux marchands qui sillonnaient le vaste Océan et se rejoignaient à Aden, d'une façon que le pouvoir mamlūk, bien éloigné des rives de la mer Rouge et de l'Océan ne pouvait assurer. Les Rasūlides mettaient en scène le caractère indispensable de leur rôle d'intermédiaire marchand et l'efficacité de leur accès aux flux des biens orientaux.

L'étude des premiers échanges d'ambassades entre Mamlūks et Rasūlides permet d'aller plus loin. Dès 666/1268, comme le précise Ibn 'Abd al-Zāhir, les envoyés du sultan du Yémen furent exemptés de taxes sur les colis d'épices avec lesquels ils étaient venus (II-a). La négociation fut habilement menée, en se couvrant d'un noble dessein, servir le ğihād. L'usage de ce langage commun permit de toute évidence de justifier la mise en place d'un régime d'exemption fiscale favorable. Les récits des ambassades ultérieures se font discrets sur ce point, mais un passage d'une lettre rédigée à la fin $\mathrm{du} \mathrm{VIII}^{\mathrm{e}} / \mathrm{XIV}^{\mathrm{e}}$ siècle par le sultan rasûlide alAšraf Ismā'îl laisse peu de doute sur la permanence de tels privilèges dans la seconde moitié $\mathrm{du} \mathrm{VIII} / \mathrm{XIV}^{\mathrm{e}}$ siècle pour les agents du pouvoir rasūlide en Égypte, à un moment où ce dernier s'affirmait plus que jamais comme un État marchand ${ }^{28}$. L'ordre diplomatique mamlūkorasūlide obéissait donc à un enjeu économique bien réel, la plupart du temps dissimulé par les sources mais qui se laisse appréhender dans leurs interstices.

En effet, les récits des chroniqueurs et des secrétaires de chancellerie notent principalement l'exceptionnel, l'extraordinaire : tel présent contenant un nombre de chevaux tout à fait élevé, tel autre comprenant un ours noir, symboles de la munificence de l'expéditeur, toute chose rare se laissant difficilement estimer. Mais une fois installée la routine de l'échange, l'évaluation du présent obéit à une comptabilité tatillonne : dès sa réception, le présent est passé au crible des secrétaires des bureaux privés du souverain. L'ensemble est décompté et l'on peut présenter au souverain une estimation globale de la valeur du présent ${ }^{29}$. Plus encore, plusieurs passages dans les sources mamlūkes montrent qu'à partir du début $\mathrm{du} \mathrm{VIII}^{\mathrm{e}} / \mathrm{XIV}^{\mathrm{e}}$ siècle au moins, le présent rasūlide fut réparti selon des règles

\footnotetext{
27 Sur l'adaptation du rituel diplomatique mamlūk dans le contexte mongol, voir les exemples cités par A. F. BROADBRIDGE, «Diplomatic Conventions in the Mamluk Sultanate », Annales Islamologiques, 41 (2007), p. 112-115.

${ }^{28}$ Al-QALQASANDI, Subḥ al-a '̌̌ă’’.., op. cit. n. 7, VIII, p. 72-76. Voir aussi, à ce propos, VALLET, L'Arabie marchande..., op. cit. n. 5, p. 524-526.

${ }^{29}$ Voir l'ambassade VIII (texte d'al-Maqrīzī).
} 
strictes entre les différents émirs qui composaient l'armature du régime mamlūk ${ }^{30}$. Le présent obéit ainsi à une logique de rente et sa valeur économique s'avère tout aussi importante que sa valeur politique et diplomatique.

Les composantes du présent, évaluées selon les mêmes règles que n'importe quel objet du marché, s'intégraient dans des réseaux de circulation et d'échange plus vastes, mettant en jeu des mécanismes financiers extrêmement complexes, qui n'ont été que récemment explorés pour la Syrie et l'Égypte du dernier siècle du Moyen Âge ${ }^{31}$, mais restent encore à déchiffrer pour les siècles qui précèdent. En effet, il est maintenant clairement établi que les États islamiques situés sur les grandes routes du commerce eurasiatique à la fin du Moyen Âge ne se contentèrent pas de percevoir une partie des richesses qui s'y échangeaient par le simple prélèvement fiscal. À des échelles diverses et de façon variable, tous les pouvoirs islamiques liés à l'Océan - au premier chef les Rasūlides du Yémen, mais aussi l'Inde des sultans de Delhi, l'Ilkhānat mongol d'Iran et, à partir de la fin du VIII $/ \mathrm{XIV}^{\mathrm{e}}$ siècle, les Mamlūks d'Égypte - eurent une présence très active sur les marchés en se faisant acheteurs et vendeurs dans des proportions qui dépassaient largement les besoins d'approvisionnement de l'État ${ }^{32}$. Il en allait ainsi dans le port d'Aden où le pouvoir rasūlide vendait chaque année des chevaux et de la garance appartenant au sultan ou à l'administration, ayant accès en retour à un marché d'une exceptionnelle richesse qui lui permettait de s'approvisionner aisément en épices et autres produits de l'océan Indien ${ }^{33}$. Pesés, évalués selon leur valeur marchande, les présents rasūlides et mamlūks étaient-ils autre chose que l'une des facettes de ce commerce d'État à État?

C'est ainsi que la dimension politique du rituel diplomatique en vint à s'effacer à partir de la fin $\mathrm{du} \mathrm{VIII}^{\mathrm{e}} / \mathrm{XIV}^{\mathrm{e}}$ siècle derrière les enjeux économiques d'un commerce mené de façon croissante par les deux sultans et leur entourage. L'insistance dans les sources rasūlides sur l'arrivée régulière du «présent égyptien » au Yémen, à compter des années 780/1380 ${ }^{34}$ est à mettre en parallèle avec le rôle croissant du Bureau privé (Dî̄ān al-mufrad) et des marchands du sultan (tāğir al-sulțān) dans les finances de l'État mamlūk, au moment où ce dernier était refondé par Barqūq à compter de $1382^{35}$. Le cadeau envoyé annuellement par le maître de l'Égypte était en effet à la mesure des bénéfices lucratifs qu'il comptait retirer du commerce mené par ses agents avec cet État marchand qu'était alors devenu le sultanat rasūlide. L'échange diplomatique reposait alors sur un investissement matériel savamment calculé : le « don » du souverain mamlūk n'appelait rien d'autre en retour que l'ouverture d'un lucratif marché.

\footnotetext{
${ }^{30}$ Voir les ambassades X et XVII.

${ }^{31}$ F. J. Appellaniz Ruiz De Galarreta, Pouvoir et finance en Méditerranée pré-moderne : le deuxième État mamelouk et le commerce des épices (1382-1517), Barcelone, 2009.

${ }^{32}$ Sur le commerce d'État dans le domaine mongol, voir en particulier D. AIGLE, Le Fārs sous la domination mongole. Politique et fiscalité, $X I I I^{e}-X V^{e}$ siècle, Louvain, 2005 ; T. T. ALLSEN, « Mongolian Princes and their Merchants Partners, 1200-1260 », Asia Major, 3 (1989), n 2, p. 83-126, et ID., Commodity and Exchange in the Mongol Empire. A Cultural History of Islamic Textiles, Cambridge, 2001.

${ }^{33}$ Voir, à ce sujet, VALLET, L'Arabie marchande..., op. cit. n. 5, p. 165-235 (chap. 3 : Le fisc d'Aden, percepteur, acheteur et vendeur).

${ }^{34}$ Voir les ambassades XXIV, XXV, XXVI, XXVII-f, XXVIII, XXIX, XXX, XXXI, XXXII.

35 VAllet, L'Arabie marchande..., op. cit. n. 5, p. 522-527, et I. DAISUKE, «The Establishment and Development of al-Dīwān al-mufrad : Its Background and Implications », Mamlūk Studies Review, 10 (2006), p. 117-140.
} 
L'historiographie a pourtant de longue date tracé une ligne de démarcation nette et forte entre échange marchand et non marchand, la diplomatie étant perçue dans ce cadre comme la formalisation de l'échange non marchand entre deux pouvoirs ou deux États. Dans le sillage de Polanyi ${ }^{36}$, il est courant de considérer que l'échange non marchand, dans les sociétés pré-modernes, précède l'échange marchand de longue distance, la relation diplomatique rendant possible la circulation des marchands en toute sécurité entre les parties prenantes. L'étude du cas mamlūko-rasūlide invite à revisiter cette question en considérant un ordre diplomatique venu se superposer à un système mercantile préexistant dans le cadre du Kārim, cette saison de navigation et de commerce qui anima les rives de l'Égypte et du Yémen entre le $\mathrm{V}^{\mathrm{e}} / \mathrm{XI}^{\mathrm{e}}$ et le $\mathrm{IX}^{\mathrm{e}} / \mathrm{XV}^{\mathrm{e}}$ siècle. Manifestation principale d'une relation de «bon voisinage » établie dans le contexte bouleversé du milieu du $\mathrm{VII}^{\mathrm{e}} / \mathrm{XIII}{ }^{\mathrm{e}}$ siècle, l'échange régulier d'ambassades entre Ta'izz et Le Caire ne peut se comprendre en dehors des codes et de modes de fonctionnement des réseaux marchands qui structuraient le commerce de longue distance dans le bassin de la mer Rouge. L'intensité du négoce, la place décisive qu'occupaient les produits venus de l'Orient dans la culture matérielle des élites du Yémen tout autant que de l'Égypte et de la Syrie, ont rendu possible l'émergence d'un langage diplomatique commun, dans lequel l'art du compromis politique s'exprimait d'abord en terme de profitables transactions et d'investissements partagés.

Éric VALLET

Université Paris 1 Panthéon-Sorbonne Orient et Méditerranée (CNRS, UMR 8167)

36 Trade and Market in the Early Empires, Economics in History and Theory, éd. K. POLANYI, C. M. ARENSEBERG, H. W. PeARson, New York, 1957, trad. fr., Les systèmes économiques dans l'histoire et dans la théorie, Paris, 1975. 


\section{Annexe : \\ Inventaire et traduction des sources sur les ambassades entre Rasūlides et Mamlūks ${ }^{37}$}

\section{Première période : Normalisation des relations}

Les sources sont peu explicites sur les premiers échanges diplomatiques entre Mamlūks et Rasūlides. La confrontation a tout d'abord lieu à La Mekke, lors du grand pèlerinage où se retrouvaient des représentants des deux puissances. Selon le principal chroniqueur yéménite $\mathrm{du} \mathrm{VII} / \mathrm{XIII}$ siècle Ibn Hātim, témoin oculaire des faits, le sultan rasūlide al-Muẓaffar Yūsuf aurait fait lever en 659/1261 l'étendard rasūlide avec l'étendard des Mamlūks accrochés l'un à l'autre sur le mont 'Arafat, la veille du Grand Aïd. Interrogé par ses proches, al-Muzaffar Yūsuf aurait justifié ce geste par la victoire du sultan mamlūk al-Malik Quțuz contre les Mongols à 'Ayn Ğālūt (IBN ḤATIM, Al-simt al-ghālī al-thaman, p. 348).

\section{Ambassade de 661/1263}

L'échange de présents diplomatiques et d'ambassadeurs est mentionné de façon laconique dès l'année 661/nov. 1262-oct. 1263 par le chroniqueur égyptien al-Maqrīzī († 1442), d'après une source plus ancienne : «En cette année-là arriva le présent du Yémen » (Kitāb al-sulūk..., op. cit. n. 6, I, 2, p. 501).

\section{Ambassade de 666/1268}

Il faut toutefois attendre l'année 666/1268 pour que l'arrivée d'une ambassade rasūlide soit rapportée en détail dans deux sources indépendantes contemporaines, issues du domaine mamlūk :

a) IBN 'ABD AL-Z̄ĀHIR, A1-rawḍ al-zāhir, p. 290. Description résumée dans AL-MAQRIZI, Kitāb al-sulūk..., op. cit. n. 6, I, 2, p. 563-564, traduite en français par J. SUBLET, Les trois vies du sultan Baibars, p. 131, reprise en partie dans la présente traduction (șafar 666/oct.-nov. 1267).

Les envoyés du souverain du Yémen arrivèrent [devant Baybars]; ils lui présentèrent vingt chevaux surmontés de caparaçons (barkaștawānāt) ${ }^{38}$ de satin brodé, plusieurs éléphants et une onagre à la robe rayée ( 'attābiyya), qui sont les meilleurs animaux pour ce qui est de la couleur, puis, comme de coutume, des quantités de musc, d'ambre, de bois d'aloès de Qumār et de Kalāh ${ }^{39}$, d'objets en argent (fiḍ̣ịyāt), de grès (yašm) et de porcelaine chinoise. Le présent fut accepté et on lui fit expédier un présent, un drapeau (sanğaq), et une robe d'honneur, ainsi que l'emblème $\left(\check{s i}^{\dagger} \bar{a}^{\prime} r\right)$ du sultanat. [Le sultan du Yémen] demanda par la bouche de son envoyé une tunique (qamīss) choisie parmi les vêtements (malābis) du sultan [mamlūk] qui serait un gage de sûreté personnelle (kāna qad sa'ala fí-hi

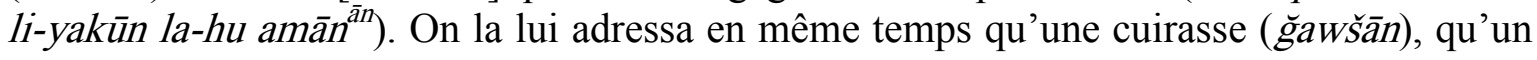

\footnotetext{
${ }^{37}$ Sauf indication contraire, les traductions sont de l'auteur de l'article.

${ }^{38}$ Voir DozY, Supplément aux dictionnaires arabes, I, p. 77.

${ }^{39}$ Il s'agit de deux types de bois d'aloès d'Asie du Sud-Est particulièrement réputés. Qumār correspond au pays des Khmers, tandis que Kalāh est un port médiéval célèbre de la péninsule malaise.
} 
katr (?) et d'autres pièces d'armes et [le sultan mamlūk] lui fit dire : « Nous vous avons envoyé à la fois un costume de paix et un costume de guerre. Ce dernier se compose de vêtements que nous avons portés sur les champs de bataille. » On lui envoya aussi des rapaces. Le sultan [mamlūk] ordonna qu'on écrive [au sultan du Yémen] en lui donnant le titre de « Son altesse auguste et royale le sultan » (al-maqām al- 'ālī al-mawlawī al-sultānī, ce qui indique un souverain de troisième rang). Et Baybars y traça de sa main : «Le mamlūk ». L'émir Fahr al-Dīn al-Muqri' partit avec le présent. Les droits qui étaient sur les épices arrivant avec les envoyés [du sultan du Yémen] furent exemptés. Le marchand qui les transportait (al-tāğgir bi-hâa) arriva en compagnie d'Ibn al-Mākasānī, l'un des deux envoyés. Il indiqua que la mère du souverain du Yémen l'avait expédié pour les combattants du ğihād et pour faire acte de piété. Il déposa le montant [des épices] dans le Trésor (al-ḩizāna) et lorsque le sultan partit en expédition (gazāt), il en dépensa une partie pour des mangonneaux [...] et il racheta les prisonniers avec le reste.

\section{b) AL-YunINI, Dhayl mir'āt al-zamān, II, p. 374.}

En 666/1268 arriva l'envoyé d'al-Muẓaffar Šams al-Dīn Yūsuf maître du Yémen en Égypte avec un éléphant, un âne sauvage rayé de blanc et de noir, des chevaux, du musc, de la porcelaine, de l'ambre. Il demanda la reconnaissance (mu'âdada)? 'addaya: partager) et s'engagea à dire le prêche du vendredi (huța) en son nom dans son pays. Le sultan tint audience le mercredi 21 rabī $^{`}$ I, convoqua l'envoyé et accepta le présent. Il envoya sa réponse avec l'émir Faḩr al-Dīn Ayāz al-Muqrī, portant une robe d'honneur, un drapeau (sanğaq) et une investiture pour le sultanat (taqlīd bi-1-sulțāna).

Signe de l'importance décisive de cette ambassade, qui marque la normalisation des relations mamlūko-rasūlides, le chroniqueur yéménite Ibn Hātim signale de son côté l'arrivée en 666/1268 d'un envoyé d'al-Malik al-Z̄āhir (Baybars) avec des lettres et des cadeaux (IBN HATIM, Al-simt al-gālī al-thaman, p. 377, repris par AL-HazRAGI, Al- 'uqūd al-lu'lu'iyya, I, p. 152).

\section{Deuxième période : Des échanges diplomatiques très réguliers à la fin du $\mathrm{VII}^{\mathrm{e}} / \mathrm{XIII}^{\mathrm{e}}$ siècle}

Peu de traces des ambassades échangées au cours des trois dernières décennies $\mathrm{du} \mathrm{VII}^{\mathrm{e}} / \mathrm{XIII}$ siècle ont été conservées (aucune dans les sources yéménites), mais il faut plutôt y voir le résultat de la normalisation des relations mamlūko-rasūlides. En dehors de situations exceptionnelles, il n'y a guère de raisons de les signaler.

\section{Ambassade de 669/1271}

La biographie royale du sultan Baybars signale une seule autre ambassade au Caire du vivant de ce sultan, en šawwāl 669/mai 1271 sans s'appesantir sur sa description (IBN 'ABD ALZAHIR, Al-raw ̣̣ al-zāhir, op. cit. amb. II-a, p. 389, repris par AL-MAQRIZI, Kitāb al-sulūk..., op. cit. n. 6, I, 2, p. 595).

En ce mois [šawwāl 669] arriva le présent du maître du Yémen dans lequel se trouvaient des objets précieux, un ours noir ( $d u b b$ aswad) et un éléphant. 


\section{Ambassade de 674/1276}

Les termes de la présentation sont presque identiques pour celle de rağab 674/janvier 1276 (IBN AL-FURAT, Ta'rīh al-duwal..., op. cit. n. 8, VII, p. 44, reprise par AL-MAQRIZI, Kitāb alsulūk..., op. cit. n. 6, I, 2, p. 621).

Au mois de rağab 674, l'envoyé du maître du Yémen arriva avec les cadeaux dont l'éléphant, le rhinocéros, les onagres à robe rayée (al- 'attābî) et différentes sortes d'objets précieux, d'épices et de cadeaux divers. Le sultan renvoya un cadeau précieux avec l'envoyé.

\section{Ambassades de 680-681/1281-1282}

Elles correspondent à l'avènement du nouveau sultan mamlūk Qalāwūn et sont rapportées avec précision par divers chroniqueurs mamlūks. Au mois de rağab 680/oct.-nov. 1281, le sultan al-Manșūr Qalāwūn écrivit à al-Muzaffar Yūsuf, maître du Yémen pour lui annoncer la victoire contre les Mongols à Himṣ. Ibn al-Furāt donne le texte de cette lettre (Ta'rịh alduwal..., op. cit. n. 8, VII, p. 223-224). Puis une ambassade du Yémen, emmenée par Majd al-Dīn ibn Abī'l-Qāsim et Tāj al-Dīn et Muhȳī al-Dīn Ibn al-Baylaqān̄̄, arriva au Caire le 27 ša 'bān/10 déc. 1281, alors que le sultan mamlūk al-Manșūr Qalāwūn rentrait en cortège dans la ville après sa victoire. Le sultan les fit emmener pour qu'ils voient la procession et soient impressionnés par le spectacle (BAYBARS AL-MANȘURI, Kitāb al-tuḥfa al-mulūkiyya fì al-dawla al-turkiyya, p. 103). Il les reçut en audience le 16 ramaḍān/29 déc. 1281 selon Ibn alFurāt ( Ta'rīh al-duwal..., op. cit. n. 8, VII, p. 228).

Le 16 ramaḍān de cette année, les envoyés du Yémen se présentèrent devant le sultan et lui demandèrent une tunique (qamīṣ) valant garantie (amān) ainsi qu'un acte détaillant cette garantie (șūrat amān) de sa main. Il répondit positivement à cela, les honora d'une tunique, et on rédigea un acte détaillant la garantie (șürat amān) pour lui et pour ses enfants. Le sultan fit savoir qu'il n'était pas de coutume de faire cela ou quelque chose de similaire, mais qu'il leur avait répondu pour honorer leur maître (makhdūm) [...] Il leur expédia des présents, des objets précieux, des pièces d'émeraudes, des chevaux des Mongols (akādīsh) et leur harnachement.

Al-Maqrīzī complète cette description avec la liste des présents (Kitāb al-sulūk..., op. cit. n. 6, I, 3, p. 702-703, source non identifiée).

Le jeudi 17, le sultan tint audience (jalasa) ; on lui présenta le présent (hadiyya) du maître du Yémen qui se trouvait entre les mains de ses employés, qui étaient Majd al-Dīn b. Abī al-Qāsim et le qāộ̄ Muḥȳi al-Dīn Yaḥyā b. al-Baylaqānī. Le sultan accepta son présent qui était composé de merveilles (tarā'if) du Yémen, bois d'aloès, ambre, porcelaine de Chine, lances de qanā (rimāḥ al-qană), etc.

Une copie de la lettre d'amān donnée par al-Manșūr Qalāwūn se trouve dans le manuscrit Arabe 4440 de la BNF (fol. 65a, d'après BAUDEN, «Les relations diplomatiques... », loc. cit. n. 20, p. 18).

En outre, Ibn al-Furāt (Ta'rīh al-duwal..., op. cit. n. 8, VII, p. 234) précise l'envoi de deux émissaires du sultan mamlūk en réponse à l'ambassade yéménite : l'émir Nāṣir al-Dīn ibn al- 
Hasan̄̄ al-Jazarī et le qāḍ̄ Šaraf al-Dīn Ibrahīm b. Farağ, secrétaire du sultan (kātib al-darğ al-šarīff), en compagnie de son fils. Le qāḍī Šaraf al-Dīn mourut en route vers le Yémen à la fin de ğumādā II 681/oct. 1282. La nouvelle arriva au Caire au mois de šawwāl, soit quatre mois plus tard (ibid., VII, p. 258).

\section{Ambassade de 684/1285}

Une dernière ambassade mentionnée pour le règne de Qalāwūn atteste la richesse du présent yéménite (IBN AL-FURAT, Ta'rīh al-duwal..., op. cit. n. 8, VIII, p. 28-29, repris par ALMAQRIZI, Kitāb al-sulūk..., op. cit. n. 6, I, 3, p. 729).

Le samedi $1^{\text {er }}$ de dhū al-qa'da de cette année là [684/29 déc. 1285] arriva l'envoyé du souverain du Yémen, accompagné de cadeaux et de présents. Il se présenta devant al-Malik al-Manșūr. Parmi les cadeaux se trouvaient treize eunuques (huddām), dix chevaux, des esclaves non châtrés (fuhūI), un éléphant, un rhinocéros (harkand), huit brebis ( $\left.n i^{\top} \bar{a} \bar{g}\right)$, huit perroquets (bibg $\vec{a})$, trois pièces de grand bois d'aloès, chaque pièce étant portée par deux hommes, quarante lances de qana ${ }^{40}$, portées par un chameau, et en épices ce que pouvaient porter soixante-dix chameaux; en tissus (qumāšs) ce qui se portait sur cent paniers ; cent plateaux de bronze (nahāss) portant des objets précieux (tuhaf) du Yémen. Il accepta cela et honora l'envoyé selon la coutume.

\section{Troisième période : Crise passagère et rétablissement des échanges diplomatiques mamlūko-rasūlides (703-730/1304-1330)}

La première décennie $\mathrm{du} \mathrm{VIII}^{\mathrm{e}} / \mathrm{XIV}^{\mathrm{e}}$ siècle voit une crise passagère des relations mamlūkorasūlides dans le contexte instable des deux premiers règnes du sultan mamlūk al-Nāșir Muhammad, alors que la réalité du pouvoir est disputée entre les grands émirs de son père. À la différence des ambassades du VII $/$ XIII ${ }^{\mathrm{e}}$ siècle, cette séquence événementielle apparaît aussi bien dans les sources syro-égyptiennes que dans les sources yéménites. 'Imād al-Dīn Idrīs alHamzī et Ibn 'Abd al-Mağîd, principaux chroniqueurs rasūlides pour le début du $\mathrm{VIII}^{\mathrm{e}} / \mathrm{XIV}^{\mathrm{e}}$ siècle sont en effet deux témoins directs, et présentent une version des faits largement favorable au sultan rasūlide, en insistant sur sa bonne disposition vis-à-vis des Égyptiens.

\section{Ambassade de 703/1304}

Al-KhazRAJI, Al-'uqūd al-lu'lu'iyya, éd. CYER, I, p. 289.

L'émir Badr al-Dīn Maktūb al-Muraqqabī arrive comme ambassadeur d'Égypte avec la nouvelle de la victoire des musulmans contre les Tatars.

Ibn 'Abd al-Mağīd, Bahğat al-zaman..., op. cit. n. 18, p. 225-227.

Au mois de ša 'bān [703/mars 1304] arriva l'envoyé égyptien, l'émir Badr al-Dīn Baktūt alMarqanī pour annoncer la victoire des musulmans sur les Mongols. Le sultan est alors alMalik al-Nāṣir Muhammad b. Qalāwūn et les administrateurs de l'État les deux émirs Sayf al-Dīn Salār, nā'ib al-sultāna et l'émir Rukn al-Dīn Baybars al-Jashnakīr (al-Malik al-

\footnotetext{
${ }^{40}$ Un ḥiml de lances de qanā d'après al-Maqrīīī.
} 
Muẓaffar). L'envoyé fut accueilli en présence des notables de l'État (a yān al-dawla alsharīa) et des émirs. Il se présenta à l'audience (al-maqām al-sharîf al-sultānî̀) à Ta'izz. [Poème de 'Imād al-Dīn Idrīs sur l'émerveillement de l'envoyé devant le sultan rasūlide (7 vers)]

Le sultan ordonna de donner à l'envoyé un lieu qui convenait à sa condition et lui prodigua ses faveurs complètes. Puis l'ambassadeur repartit avec la réponse du sultan scellée.

\section{Ambassade de 705}

Ibn 'Abd al-Mağīd, Bahğat al-zaman..., op. cit. n. 18, p. 235.

AL-KhAzRAJ̄̄, Al-'uqūd al-lu'lu'iyya, éd. CYER, I, p. 298. Liste donnée par G. WIET, Marchands, p. 92.

Le sultan rasūlide veut envoyer un présent avec l'émir Asad al-Dīn Muhammad b. Nūr. Mais on apprend que la situation est tendue en Égypte, et le présent n'est pas envoyé. Il est finalement envoyé plus tard:

Objets en argent de différentes sortes, tels que bassins (țušüt), aiguières (abārīq), plateaux (șalāhiiyyāt), brûle-parfums (majāmir), boules (akr), étuis (qurābāt); des bâtons (sawārî) de bois d'aloès et de santal, de gros morceaux d'ambre, des vessies (nawāfij) de musc, un choix magnifique de porcelaine de Chine et de grès (yashm), notamment des assiettes (șụ̂un) et des bols (zubāầ), des plateaux (sakārij), d'une beauté indescriptible ; des eunuques abyssins (al-khuddām al-ḥabashî̀) ; du bambou de l'Inde (al-qanā al-hindî̀) ; des canapés de Chine (al-marāqīd al-șiniyya); des consoles dorées (al-marākib almudhahhaba); de fines mousselines (shāshāt) et des tissus de Bailakan (al-silqāniyāt) ; une quantité considérable de brocarts de Chine (al-thiyāb al-mudhahhaba al-șiniyya); des vases $(a w \bar{a} n \bar{l})$ et des plateaux $(a t ̦ \bar{a} q)$; des coffres (șanābi $\bar{q})$ pleins de musc en grains (almufarragh), du shah-sini (racine d'une plante chinoise), du camphre raffiné (al-țāzza) ; ce qui relève des hawāà'ij khānāt, comme de nombreux bahār de poivre, des clous de girofle, du gingembre, de la laque, du bois de brésil ; des éléphants, des onagres à la robe rayée (al'attābî), des girafes, tous ces animaux caparaçonnés de satin broché d'or, des chevaux arabes de race correspondant au rang (ḥāt) du destinataire. Le tout fut expédié sur deux grands navires. L'envoi des présents de cette sorte ne devait pas être retardé au-delà de deux ou trois ans; il était en effet nécessaire pour affirmer l'affection et l'amitié (almawadda wal-mahabba), ainsi que la perpétuation du compagnonnage (suḥba) qui avait été conclu. Je n'ai détaillé le contenu visible ( 'iyān) de ce présent que parce qu'il témoigne de la grande vertu du sultan [qui l'a expédié].

Les sources égyptiennes présentent des versions divergentes. Al-Maqrīzī, sans indiquer sa source, évoque l'interruption du présent yéménite par al-Mu'ayyad Dāwūd et l'envoi d'une lettre de menace au nom du calife abbasside du Caire en 704/1304-1305 (AL-MAQRIZI, Kitāb al-sulūk..., op. cit. n. 6, II, 1, p. 7).

[En 704,] de nombreux marchands vinrent se plaindre d'al-Mu'ayyad roi du Yémen. De plus, il avait interrompu le présent qui était porté depuis le Yémen d'un montant de six mille dinars. On achetait avec cela des marchandises qui étaient expédiées aux forteresses ismaéliennes, accompagnées du présent réservé au sultan. Al-Muẓaffar Yūsuf b. al-Manșūr 'Umar b. 'Alī b. Rasūl l'avait fait porter pendant quarante ans, puis son fils al-Ašraf l'avait fait porter. Lorsque Hizabr al-Dīn Dāwūd b. al-Muẓaffar Yūsuf b. al-Manșūr 'Umar b. 'Alī 


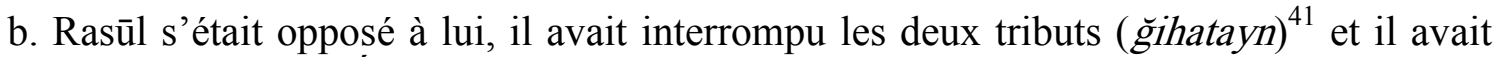
méprisé le sultan d'Égypte. On lui écrivit pour le condamner et le menacer. Cela lui fut envoyé avec Nāșir al-Dīn al-Țūrī et Shams al-Dīn Muḥammad b. 'Adlān. Tous deux emportèrent aussi une lettre du calife, faite de condamnation et de menace et lui ordonnant de porter le montant fixé (al-muqarrar) comme de coutume.

Toutefois, la lettre du calife abbasside al-Mustakfì bi'llāh, intégralement conservée dans l'encyclopédie d'al-Qalqašandī, est datée de 705 par les auteurs issus de la chancellerie, «lorsque le souverain du Yémen s'abstint d'envoyer les présents coutumiers à la cour du sultan (al-abwāb al-sharīfa) en Égypte » (AL-QALQASANDI, Șubḥ al-a '̌̌ă'..., op. cit. n. 7, VI, p. 422-425).

De façon plus sûre, l'émir Baybars al-Manșūrī, l'un des deux «protecteurs » de l'État mamlūk à cette date et auteur de deux chroniques, mentionne l'arrivée du présent rasūlide en 705, mais reproche simplement à ce présent d'avoir été d'une valeur moindre que les précédents (BAYBARS AL-MANȘURI, Kitāb al-tuḥfa..., op. cit. amb. V, p. 383, abrégé par ALMAQRIZI, Kitāb al-sulūk..., op. cit. n. 6, II, 1, p. 20-21).

L'envoyé d'al-Malik al-Mu'ayyad, maître du Yémen, arriva au Caire [dhū al-higğğa 705]. Il apporta le présent yéménite (al-hadiyya al-yamaniyya), [composé] d'épices, de bois pour les lances (qanā), de foulards ( $\check{s} \bar{a} \breve{s} \bar{a} t)$, d'objets précieux (tuhaf). Son présent fut estimé et il était d'une valeur moindre que les présents envoyés habituellement par son père. On lui envoya les nobles lettres (al-kutub al-sharīfa) pour le couvrir de blâmes, de menaces, de paroles fortes ( $\dot{i g} l \bar{a} z)$ et de menaces ( wa ‘'̄ó) par l'intermédiaire de Badr al-Dīn Muhammad al-Ṭūrī, l'un des commandants de la halqa. On ne l'accueillit pas, on ne le renvoya avec aucune lettre, ni aucun envoyé, et il s'en repartit après un certain temps.

Cette date de 705 pour l'ambassade rasūlide qui suscita le courroux égyptien et l'envoi d'une lettre de menace est confirmée par le chroniqueur yéménite al-Hazrağ̄i (AL-KHAZRAJI, Al'uqūd al-lu'lu'iyya, I, p. 303).

\section{Ambassade de 707/1307}

L'envoyé égyptien au Yémen, parti en 705/1305, revint sans présent « complémentaire », et l'émir Salār décida de lancer une expédition navale contre le Yémen en 707/1307. L'entreprise n'aboutit pas et se solda par l'envoi d'un nouveau messager égyptien au Yémen, comme le confirment aussi bien Ibn 'Abd al-Mağīd (point de vue yéménite) qu'Ibn Hağar al'Asqalānī (point de vue égyptien).

a) AL-KHAzRAJĪ, Al-'uqūd al-lu'lu'iyya, éd. CYER, I, p. 307-308.

Cette année-là, l'émir Sayf al-Dīn Salār, nā'ib al-sulțāna en Égypte, voulut expédier l'émir Baybars avec une grosse armée vers le Yémen [...] Puis le sultan changea d'avis et prit prétexte des retards dans l'expédition. Lorsque le sultan al-Malik al-Mu'ayyad apprit cela, il interdit le Kārim cette année-là jusqu'à ce qu'arrive le messager annonçant cela. L'affaire se termina finalement par l'envoi d'un messager d'Égypte vers le Yémen et d'un enturbanné (muta'ammim). Le messager était un homme appelé al-Sa'dī, mamlūk d'alMalik al-Ẓāhir. Et l'enturbanné était le qāọ̄i Shams al-Dīn Muḥammad b. 'Adlān, un juge.

\footnotetext{
${ }^{41}$ Note de l'éditeur : impôt ou tribut fixe, voir AL-ĞANADI, al-Sulūk..., op. cit. n. 13, I, p. 373 et 688.
} 
Le contenu de la lettre était qu'il ne se passerait rien et disait que le sultan avait changé d'avis sur ce qu'il avait décidé, et qu'il souhaitait conclure une trêve (șuḷ̂) et almuwāda'a.

b) IBN ḢAGAR, Al-durar al-kāmina..., op. cit. n. 6, III, p. 333, nº 891.

Le sultan envoya un ambassadeur au souverain du Yémen au début de l'année 707/été 1307 [...] Ils voulaient alors attaquer le Yémen. Mais les marchands (al-tujjār) conseillèrent (ashāru $\vec{u})$ de retarder cela et d'envoyer un messager. Ils acceptèrent, et Shams al-Dīn Sunqur al-Sa'dī et le shaykh Shams al-Dīn ibn 'Adlān partirent pour cela.

\section{Ambassade de 711/1312}

La fin de la crise fut certainement scellée en 708/1308 ou 709/1309 par l'envoi d'une ambassade rasūlide au Caire, bien que les sources n'en aient pas conservé de trace. Celle de 711/1310 est en revanche bien attestée par Baybars al-Manșūrī (Kitāb al-tuḥfa..., op. cit. amb. V, p. 238, résumé par AL-MAQRIZI, Kitāb al-sulūk..., op. cit. n. 6, II, 1, p. 107).

Dans la première dizaine du mois [dhū al-ḥiğğa 711/avr. 1312] arriva à la cour du sultan (al-abwāb al-sultāniyya) l'envoyé d'al-Malik al-Mu'ayyad Hizabr al-Dīn, souverain (șāhib) du Yémen, accompagné de présents et d'objets précieux : bois d'aloès de Qumār, ambre de Shihr, musc, marchandises indiennes, le qanā al-khatțī, les chevaux et les eunuques (khuddām). Ces cadeaux (hidāya) étaient portés par deux cents chameaux, et l'envoyé des Banū Rasūl apparut/comparut devant l'audience sultanienne, que Dieu l'exalte et affermisse son pouvoir. Les plus grands des émirs, les chefs de l'armée (muqaddamū al-'asākir), khawāṣ̦ al-dawla et l'élite du royaume (a'yān al-mamlaka) s'étaient rassemblés. Il vit ce qui ... son message fut entendu, ses cadeaux furent présentés et on remercia pour le service (khidma) de celui qui l'envoyait et son obéissance. Il descendit à Dār al-ḍiyāfa selon la coutume de ses prédécesseurs ... Notre maître le sultan partagea ces cadeaux.

\section{Ambassade de 715/1315 et 716}

Après 711/1312, les ambassades ne sont plus décrites en détail, sans doute parce qu'elles redeviennent très régulières. Al-Maqrīzī signale les attaques de bédouins deux années de suite (715/1315 et 716/1316) contre les envoyés du maître du Yémen, sans que l'on sache s'il s'agit de deux événements distincts.

a) AL-MAQRīzī, Kitāb al-sulūk..., op. cit. n. 6, II, 1, p. 145-146.

En cette année-là [715/1315] arrivèrent les envoyés du maître du Yémen, Badr al-Dīn Hasan b. Ab̄̄ al-Manğā et l'eunuque Jamāl al-Dīn Fayrūz. Des 'Arab les avaient attaqués dans le désert de 'Aydhāb et leur avaient pris leur présent. Le sultan dépêcha les émirs ... vers Damqula en Nubie.

b) AL-MAQRīZī, Kitāb al-sulūk..., op. cit. n. 6, II, 1, p. 162.

En cette année-là [716/1316] des Arabes de la steppe de 'Aydhāb (barriyat 'Aydhāb) prirent les envoyés du maître du Yémen, de nombreux marchands et tous les biens qu'ils avaient. Le sultan envoya l'armée, composée de cinq cents cavaliers... le 20 de shawwāl. Ils 
partirent pour Qūṣ et de là se rendirent, au début de muharram 717, dans le désert de 'Aydhāb. Ils parvinrent à Sawākin jusqu'à rencontrer une bande (țā'ifa) appelé Hay alHalbaksa.

\section{Ambassade de 718/1318}

Elle n'est attestée que par le chroniqueur yéménite Ibn 'Abd al-Mağīd, mais est plausible après le rétablissement de la sécurité dans le désert du sud égyptien (Bahjat al-zaman..., op. cit. n. 18, p. 281, repris par AL-KHAZRAJĪ, Al-'uqūd al-lu'lu'iyya, I, p. 348).

En cette année-là partirent les envoyés vers l'Égypte. C'était l'émir Badr al-Dīn Hasan b. al-Asad et ceux qui avaient l'habitude de l'accompagner à son service. Le sultan al-Malik al-Nāșir l'accueillit de la meilleure des façons.

\section{Ambassade de ğumādā II 720/1320}

AL-MAQRīZĪ, Kitāb al-sulūk..., op. cit. n. 6, II, 1, p. 207.

En cette année-là [720] arrivèrent les envoyés du maitre (mutamallik) du Yémen avec le présent. Ils furent présentés à la citadelle le lundi 13 jumādā II/20 juil. 1320.

\section{Ambassade de 724}

AL-MAQRīZĪ, Kitāb al-sulūk..., op. cit. n. 6, II, 1, p. 254.

Arrivée des messages d'al-Mujāhid pour demander l'aide à l'Égypte. On ne répondit pas à cela.

\section{Ambassade de 725-726/1325-1326}

Le chroniqueur rasūlide al-Hazrağ̄ signale simplement le départ du Qāọ̄i Ğamāl al-Dīn Muhammad b. Mu'min «vers l'Égypte avec un cadeau précieux, par la mer, depuis le rivage de Zabīd (min sāḥil Zabīed) » et son retour au mois de dhū al-qa'da 726/oct. 1326 (ALKHAZRAJI, Al-'uqūd al-lu'lu'iyya, éd. CYER, II, p. 40 et 45). Al-Maqrīzī signale l'arrivée de ces envoyés en șafar 725/janv. 1325 (Kitāb al-sulūk..., op. cit. n. 6, II, 1, p. 259).

\section{Ambassade de 730/1330}

Les sources égyptiennes indiquent qu'une lettre du sultan mamlūk fut envoyée après l'assassinat de l'envoyé du sultan de Delhi à Aden en 730/1330 (IBN FADL ALLAH AL-'UMARI, al-Ta'rîf bi al-Mustalah al-Sharif, op. cit. n. 2, p. 48-49, repris par AL-QALQASANDI, Subḥ ala ‘šâ'..., op. cit. n. 7, VII, p. 372-373), sans que l'on sache si cet envoi a précédé ou suivi l'arrivée de deux envoyés des Rasūlides au Caire (AL-MAQRIZI, Kitāb al-sulūk..., op. cit. n. 6, II, 2, p. 322).

Le 19 šawwāl [730/5 août 1330] arrivèrent les envoyés d'al-Malik al-Mujāhid 'Alī du Yémen avec un présent. Il y avait deux éléphants. Le sultan les critiqua, car al-Mujāhid s'était emparé de l'envoyé du roi de l'Inde, avait pris le présent du sultan, puis l'avait tué. Il ordonna de les emprisonner. 


\section{Ambassade de 753-754/1352-1353}

La longue interruption des relations mamlūko-rasūlides qui suit l'affaire de 730/1330 prit brutalement fin avec l'arrestation du sultan rasūlide al-Muğāhid 'Alī à La Mekke par l'émir de la caravane égyptienne lors du pèlerinage de l'année 751/févr. 1351. Emmené en captivité au Caire, al-Muğāanid 'Alī fut finalement libéré en ša'bān 752/oct. 1351 après le versement d'une rançon et en promettant « d'envoyer le présent et l'argent chaque année » (AL-MAQRIZI, Kitāb al-sulūk..., op. cit. n. 6, II, 3, p. 839). Le retour du sultan au Yémen fut suivi par l'envoi d'une ambassade en 753/1352, qui parvint au Caire en 754/1353. Les étapes en sont minutieusement rapportées par la chronique d'al-Maqrīzī.

a) Al-KhazRAJ̄̄, Al- 'uqūd al-lu'lu'iyya, II, p. 82-83.

Au noble mois de ša bān [753/1352], le sultan [al-Mujāhid] envoya un présent considérable avec son fils al-Nāṣir Ahmmad, le Qāḍī Fatḥ al-Dīn 'Umar b. Muhammad b. alHuṭabā' et l'émir Šams al-Dīn 'Alī b. Ḥātim et le grand eunuque (țawāshî̀) Nizāàm al-Dīn Haḍīr, et tous partirent pour l'Égypte. Le grand eunuque mourut à 'Aydhāb et fut enterré là. Apprenant sa mort, le sultan envoya pour le remplacer le grand eunuque Șafì al-Dīn alRị̣̂ānī. Il partit prestement mais ne put les rattraper qu'après leur arrivée au Caire.

b) AL-MAQRīZī, Kitāb al-sulūk..., op. cit. n. 6, II, 3, p. 867.

[Au mois de rağab 753/août-sept. 1352] arriva la lettre d'al-Malik al-Muğāhid 'Alī depuis le Yémen annonçant son arrivée dans son pays, qu'il avait expédié son présent et qu'il avait remboursé leurs biens aux marchands à qui il avait emprunté, qu'il avait laissé partir les navires des marchands pour qu'ils circulent (ațlaqa marākib al-tujjār li-tasīr), mais qu'il leur avait interdit de mouiller à Jidda et de passer par La Mecque, car il abhorrait ses émirs.

c) AL-MAQRīZì, Kitāb al-sulūk..., op. cit. n. 6, II, 3, p. 886.

[Au début de l'année 754/févr. 1353] arriva la nouvelle de l'arrivée des envoyés d'al-Malik al-Mujāhid 'Alī b. al-Mu'ayyad Dāwūd b. al-Muẓaffar Yūsuf b. al-Manșūr 'Umar b. 'Alī b. Rasūl souverain (mutamallik) du Yémen à 'Aydhāb avec un présent. L'émir Âqjabā alHamawī partit à leur rencontre avec les provisions (iqāmāt), grains (anzā̄l), fourrage et nourriture $(t a b \bar{a} ' \hat{i} h)$.

d) AL-MAQRīZī, Kitāb al-sulūk..., op. cit. n. 6, II, 3, p. 892-893.

Le samedi $11 \mathrm{rabī}^{\prime}$ I [754/16 avr. 1353], les envoyés d'al-Mujāhid, maître du Yémen, arrivèrent avec son fils al-Malik al-Nāṣir, âgé de 11 ans. Ils descendirent sur le maydān, et l'émir Țāz y descendit aussi pour que lui soit présenté le cadeau, puis ils se présentèrent devant le sultan avec leur cadeau, 60 esclaves, reste de 300 qui étaient morts, 200 foulards (shāsh), 400 pièces ( $q i t^{\dagger} a$ ) de porcelaine, 150 poches (nāfija) de musc, une corne (qarn) de civette et de nombreuses pièces d'étoffe (tafășil), 150 qințār de poivre, beaucoup de choses du gingembre à l'ambre et les épices menues (afāwih) et un éléphant. Cela sans compter le cadeau pour les émirs Šayhū, Țāz, Qubilāy représentant du sultan, et pour le vizir 'Alam al-Dīn b. Zunbūr. Le présent sultanien fut porté au Șāḥib Muwaffaq al-Dīn. Les émirs ne furent pas satisfaits de cela, car le présent d'al-Mu'ayyad à al-Malik al-Nāṣir Muhammad b. Qalāwūn comportait 2000 foulards (šās̆). Toutefois, il avait été dépensé pour les envoyés, depuis leur arrivée à 'Aydhāb jusqu'à l'Hippodrome (Maydān), environ 
200000 dirhams. Tous furent revêtus de robes d'honneur, et on leur attribua chaque jour 500 dirhams. Tous les émirs se firent un devoir de les inviter (ḍiyāfa).

\section{Ambassade de 755/1354}

Elle est mentionnée de façon incidente dans la notice biographique d'Abū al-Durr Jawhar alMujāhid̄̄ al-Raḍwān̄i : envoyé par al-Mujāhid en ambassade en 755/1354, il se serait noyé à la suite d'une tempête (AL-MALIK AL-AFḌAL, Al-'ațāya al-saniyya, p. 290-291, nº 218) ou d'une attaque venue du jabal Zuqar (AL-KHAZRAJI, Al- 'uqūd al-lu'lu'iyya, II, p. 88).

\section{Ambassade non datée entre 757/1356 et 761/1360}

Al-Afụal (Al- 'ațāya al-saniyya..., op. cit. amb. XVIII, p. 259, n 179) évoque Abū al-'Abbās Aḥmad b. 'Alī b. Qabīb, surintendant des biens privés du sultan (nāzir al-khāṣș), qui fut ambassadeur du sultan al-Muğāhid en Égypte. La date de sa mort, 762/1361, implique que cette ambassade eut lieu entre celle de 755/1354 et celle de 762/1361.

\section{Ambassade de 762/1361}

Mentionnée de façon incidente dans la notice biographique d'Abū al-Faḍā'il Najīb b. 'Abd Allāh, surintendant (zimām) du palais (dār) d'al-Mujāhid (†770), envoyé comme ambassadeur en Égypte en 762/1361 (AL-MALIK AL-AFḌAL, Al-'ațāya al-saniyya..., op. cit. amb. XVIII, p. 658, no 916).

La chronique d'al-Hazraği signale le retour de cette ambassade en 763/1362 (AL-KHAZRAJI, Al-'uqūd al-lu'lu'iyya, éd. CYER, II, p. 103) :

Le 28 [rabī' II 763] arrivèrent depuis l'Égypte les ambassadeurs (sufarā'), c'est-à-dire le grand eunuque (tawāshì) Șārim al-Dīn Nağìb et le qāḍ̄ Jamāl al-Dīn Muḥammad b. 'Umar al-Sharīf, le Qāḍ̂̄ Ğamāl al-Dīn Muhammad b. 'Alī al-Fāriqī et l'émir Shams al-Dīn 'Alī b. Hâtim. De nombreux émirs des Turcs vinrent avec eux. Le sultan les accueillit de la meilleure façon.

\section{Ambassade de 767-770/1365-1368}

Cette ambassade, évoquée aussi bien dans les sources rasūlides qu'égyptiennes, résulte de l'avènement du nouveau sultan rasūlide al-Afụal al-'Abbās.

a) AL-HुAZRAĞİ, Al- ‘uqūd al-lu'lu'iyya, éd. CYER, II, p. 117.

[En 767/1365,] le qāọ̄i Jamāl al-Dīn fut envoyé comme ambassadeur (safîr) en Égypte, accompagné de cadeaux et d'objets précieux convenant au rang de celui qui offrait [le cadeau] et de celui qui le reçoit. Il partit le 10 du mois de rabī' I/24 nov. 1365 de la ville de Ta'izz [...] En 768 arriva le qāḍī Jamāl al-Dīn Muhammad b. 'Alī al-Fāriqī depuis l'Égypte avec des cadeaux du souverain d'Égypte et avec des mamlūks, le 8 du mois de șafar/13 oct. 1366.

b) AL-MAQRīZİ, Kitāb al-sulūk..., op. cit. n. 6, III, 1, p. 123 et 127.

[À la fin de 767/août 1366,] le vizir du souverain du Yémen arriva avec un présent comprenant notamment un éléphant [...] Le jeudi 3 muharram [768/9 sept. 1366] arrivèrent 
[au Caire] les envoyés d'al-Malik al-Afụal 'Abbās b. al-Mujāhid, maître du Yémen, avec un présent précieux comme de coutume. C'étaient son vizir Sharaf al-Dīn Husayn b. 'Alī al-Fāriqī et son émir ahūr Nāṣir al-Dīn. Ils se présentèrent devant le sultan et lui remirent la lettre dont ils étaient porteurs. Puis ils se rendirent sur le grand Hippodrome qui se trouvait au bord du Nil et présentèrent le cadeau [venant de celui qui les] avait envoyés le samedi 5 . Il contenait notamment un cheval ne possédant ni sexe masculin, ni sexe féminin, mais urinant par un orifice. Le présent fut accepté.

La Chronique anonyme mentionne par ailleurs le «voyage des envoyés (sufarāa) d'al-Afḍal vers l'Égypte avec de précieux présents emmenés (șhḥba) par le qāḍ̄ Jamāl al-Dīn al-Fāriqī au mois de rabī' I 768 », puis le « retour des ambassadeurs (sufarā') de l'Égypte emmenés par le très noble qāội Jamāl al-Dīn al-Fāriqī en șafar 770/sept.-oct. 1368 » (Chronique anonyme, éd. AL-HiBSHI, p. 67-68).

\section{Ambassade de 771/1370}

Al-Maqrīzī relève la mort de l'émir Aqbughā al-Yūsufí al-Hāājib en ša'bān 771/mars 1370 à Manfalūṭ, alors qu'il était parti à la rencontre du cadeau du maître du Yémen (AL-MAQRIZI, Kitāb al-sulūk..., op. cit. n. 6, III, 1, p. 187).

\section{Ambassade de 774-778/1373-1376}

La Chronique anonyme signale le « départ des envoyés (sufarā') d'al-Afụal vers l'Égypte pour la seconde fois, emmenés par le qâḍ̂̄ Jamāl al-Dīn Muḥammad b. 'Alī al-Fāriqī et l'émir Nāṣir al-Dīn al-Bahā' au mois de ramaḍān 774/mars 1373 ", puis le "retour des envoyés (sufarā') d'al-Afụal depuis l'Égypte avec les présents resplendissants (al-hadāyā al-saniyya) et les objets précieux (al-tuḥaf al-fākhira), emmenés par l'illustre qāḍ̄ Jamāl al-Dīn Muhammad b. 'Alī al-Fāriqī au mois de muharram 778/juin 1376 » (Chronique anonyme, op. cit. amb. XXI-b, p. 74 et 76).

Al-Maqrīzī confirme l'arrivée de cette ambassade au Caire en 775/1374 (Kitāb al-sulūk..., op. cit. n. 6, III, 1, p. 222) :

[Au mois de ğumādā II 775,] Sharaf al-Dīn Ḥusayn al-Fāriqī vizir du maître du Yémen arriva avec sa lettre, accompagné de l'émir ākhūr Nāṣir al-Dīn Muhammad, avec un cadeau précieux.

\section{Présent de 787/1385}

Ce bref passage de la Chronique anonyme (op. cit. amb. XXI-b, p. 91), tout comme les deux qui suivent, mentionne simplement l'arrivée des "présents d'Égypte », sans que la venue d'ambassadeurs ne leur soit explicitement associée.

Le présent (hadiyya) arriva d'Égypte, dans lequel il y avait un arbre à corail (shajar almarjān) et différents types d'objets précieux (anwā' min al-tuhaf al-făkhira), cela au mois de rabī' II 787/mai 1385. 


\section{Présent de 788/1386}

a) Chronique anonyme, op. cit. amb. XXI-b, p. 93.

Les présents (hadāyā) arrivèrent d'Égypte, comprenant différents types d'objets précieux (tuhaf) et de merveilles ( 'ağā'ib) sans précédent, le 10 rabī' I 788/11 avr. 1386.

b) Al-Khazraji, Al- 'uqūd al-lu'lu'iyya, éd. CYER, II, p. 158.

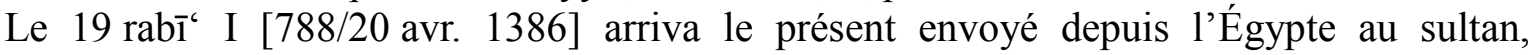
accompagné d'ouvriers soyeux d'Alexandrie.

\section{Présent de 790/1388}

a) Chronique anonyme, op. cit. amb. XXI-b, p. 98.

Le présent (al-hadiyya) arriva d'Égypte au mois de ramaḍān 790/sept. 1388.

b) Al-KHAZRAJI, Al- 'uqūd al-lu'lu'iyya, éd. CYER, II, p. 167-168.

Le 16 ramaḍān [790/18 sept. 1388] : arrivée du Qāọī Burhān al-Dīn Ibrāhīm b. 'Umar alMahallī, le marchand d'Égypte et du Kārim (al-tāğgir al-missrī al-tāğir al-kārimî̀) avec un cadeau de grande valeur dans lequel se trouvait de la nourriture et des boissons, des vêtements et des parfums, de nombreux objets précieux, des chevaux, des mulets, des chiens de chasse et des rapaces en grand nombre et d'excellente qualité.

\section{Ambassade de 798/1396}

a) Al-KhAZRAJi, Al- 'uqūd al-lu'lu'iyya, éd. CYER, II, p. 233.

Le 5 jumādā I [798/15 févr. 1396], le sultan envoya un présent précieux en Égypte en compagnie du qāộ̀ Burhān al-Dīn Ibrāhīm b. 'Umar al-Maḥallī, en réponse au présent qui était parvenu de la part du sultan al-Malik al-Zāhir Sayf al-Dīn Barqūq.

b) AL-QALQASANDI, Subḥ al-a 'šâ'..., op. cit. n. 7, VIII, p. 72-76.

Copie de la lettre envoyée par le sultan al-Ashraf Ismā'īl à Barqūq en 798/1396, par l'intermédiaire du marchand du sultan Burhān al-Dīn al-Maḥallī, marchand kārimī (7 jumādā II 798).

c) La Chronique anonyme annonce cette venue en 799/1396 (op. cit. amb. XXI-b, p. 128).

Le țawāshī Iftikhār al-Dīn Fākhr Qudsī arriva d'Égypte avec les présents (hadāyâ), les objets rares (tuḥaf), les chevaux, les mamlūks, en compagnie du qāọī Shihāb al-Dīn Aḥmad b. al-qā ḍī Burhān al-Dīn al-Maḥallī, au mois de muḥarram 799/oct.1396.

d) IBN AL-FuRAT, Ta'rīh al-duwal..., op. cit. n. 8, IX, II, p. 458-459, repris de façon abrégée par AL-MAQRIZI, Kitāb al-sulūk..., op. cit. n. 6, III, 2, p. 874.

Le 21 du mois de rabī' I 799/23 déc. 1396, les présents d'al-Malik al-Ashraf Muhammad b. al-Malik al-Afụal 'Abbās b. al-Malik al-Mujāhid Sayf al-Dīn 'Alī b. al-Malik Dāwūd b. alMuz̧affar Yūsuf b. 'Umar b. Rasūl, maître du Yémen, furent présentés, accompagnés par le qāộ̄ Burhān al-Dīn Ibrahīm al-Mahallī, al-tājir al-sulțān̄i al-ẓāhirī al-kārimī, de la main de son envoyé le țawāshī Iftikhār al-Dīn Yāqūt. Ils furent montés à la citadelle, apportés dans la cour (ḥawsh), alors que le sultan al-Zāâhir s'y trouvait, et furent remis entre ses nobles 
mains. Il s'agit de vingt esclaves (raqīq), dont dix eunuques (khuddām), quatre esclaves hommes non châtrés ( 'abīd) et six esclaves femmes ( ğawārì), une épée en acier incrustée d'or, avec un collier de cornaline, une hịyāșa d'or.

e) IBN HaGAR, Inbā'al-gumr..., op. cit. n. 25, III, p. 335.

En cette année, [Shihāb al-Dīn al-Maḥallī] se dirigea vers le Yémen par la route d'al-Ṭūr, embarqua en mer en dhū al-qa'da [799/août 1397] et y arriva l'année suivante.

f) AL-KhazRaji, Al- 'uqūd al-lu'lu'iyya, éd. CYER, II, p. 242.

$\mathrm{Au}$ mois de șafar 800/nov. 1397 arriva le présent d'Égypte au mouillage d'al-Hirda. Lorsque le sultan apprit cela, il descendit à Zabīd et y entra le lundi 14 șafar/6 nov. 1397. Une fois établi à Zabīd, il envoya le țawāshī Jamāl al-Dīn Jamīl avec trois cents hommes vers le mouillage d'al-Hirda. Il envoya avec lui un détachement de l'armée pour accompagner le cadeau. Il arriva à Zabīd le jeudi 24 șafar/16 nov. 1397. C'était un présent impressionnant, composé d'environ trente mamlūks turcs, douze chevaux de race avec des selles mughriqa et un bel attirail (âla), de nombreuses femmes esclaves, Rūmī et Arméniennes, et un médecin expérimenté, juif d'Égypte. Il y avait beaucoup de tissus, de parfums, de mets, en quantité innombrable. Le présent arriva avec le fils du qāḍ̄i Shihāb alDīn Aḥmad b. Ibrāhīm al-Maḥallī. L'arrivée du présent fut un jour mémorable.

\section{Ambassade de 800-801/1398}

AL-KHAZRAJ̄̄, Al-'uqūd al-lu'lu'iyya, éd. CYER, II, p. 246.

À la fin du mois de dhū al-hijja 800/août-sept. 1398 arriva le présent d'Égypte en compagnie du ḥâjj Aḥmad al-Khafānī [...] Le 17 șafar 801/29 oct. 1398 arrivèrent le palanquin (maḥmal) et la caravane avec les pèlerins et le cadeau d'Égypte.

\section{Ambassade de 802/1399}

AL-KHAZRAJI, Al- 'uqūd al-lu'lu'iyya, éd. CYER, II, p. 252.

Le 5 șafar 802/7 oct. 1399 arriva depuis l'Égypte le présent qui avait été envoyé par le sultan al-Malik al-Ẓāhir Barqūq avant sa mort.

\section{Ambassade de 806/1404}

Chronique anonyme, op. cit. amb. XXI-b, p. 138.

Arrivée des ambassadeurs (sufarā') et des présents (hadāya) d'Égypte vers la noble cour (al-bāb al-sharīf ; les présents étaient accompagnés par Ibn al-Warrāq, le samedi 5 du noble mois de ša'bān 806/17 févr. 1404.

\section{Ambassade de 807/1404}

Chronique anonyme, op. cit. amb. XXI-b, p. 140.

Arrivée de l'envoyé (rasū $)$ du maître de Mișr avec des lettres à la noble cour (al-bāb alsharīf). Il entra (à la cour) de la plus merveilleuse des façons, fut vêtu de vêtements précieux, et on le combla, le 27 jumādā II 807/31 déc. 1404. 


\section{Ambassade de 818/1415}

Chronique anonyme, op. cit. amb. XXI-b, p. 175.

Le présent béni (al-hadiyya al-mubāraka) du souverain de l'Égypte arriva à la noble cour au thaghr bien gardé d'Aden. Il contenait des mamlūks, des chevaux, des mulets (bighāt) avec des selles marbrées (surūj mu'arraqa), des tissus (qumāsh) et des objets rares en

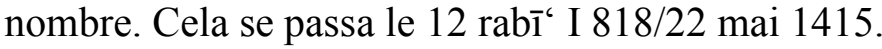

\section{Ambassade de 819-820}

a) AL-MAQRīZī, Kitāb al-sulūk..., op. cit. n. 6, IV, 1, p. 345.

Le 19 [muharram 819/19 mars 1416], le sultan tint audience à Dār al-'Adl dans la Citadelle. Zayn al-Dīn Mufliḥ, envoyé d'al-Malik [al-Nāṣir] Aḥmad b. al-Ashraf Ismā‘̄îl, souverain du Yémen, se présenta, accompagné d'un cadeau très précieux, composé de shāsh, de manteaux (uzur), d'étoffes (tafăṣīl) de soie, de porcelaine de Chine, de bois d'aloès et d'encens, de santal, etc. porté par deux cents porteurs. Il y avait aussi des selles en cornaline aux bords dorés, des civettes dont on tire le musc. Le présent fut accepté et la lettre fut lue. On hébergea son envoyé et on ordonna de lui donner ce qui convenait.

b) IBN ḤAGAR, Inbā'al-gumr..., op. cit. n. 25, VII, p. 207.

En ce mois [muharram 819/mars 1416] arriva Muflih, envoyé du maître du Yémen, avec un présent considérable pour al-Malik al-Mu'ayyad. Il honora celui qui l'apportait et ordonna de vendre le présent et de dépenser [le produit] pour la construction de la Mu'ayyadiyya. Il en obtint une grande somme. Al-Malik al-Mu'ayyad fit l'audience dans l'iwān du Dār al-'Adl [...] Il demanda à l'envoyé du maître du Yémen de se présenter et il vit ce qui l'émerveilla. Il présenta le message qu'il avait avec lui, puis le présent porté par deux cents chameaux. On le revêtit d'une robe d'honneur prestigieuse.

c) AL-MAQRīZī, Kitāb al-sulūk..., op. cit. n. 6, IV, 1, p. 367.

[En ramaḍān 819/nov. 1416,] les envoyés du roi du Yémen, des Francs de Venise et de Qarā Yūsuf furent renvoyés, chacun avec un présent.

d) AL-MAQRīZī, Kitāb al-sulūk..., op. cit. n. 6, IV, 1, p. 395.

Le 15 [rabī' II 820/1 er juin 1417], Muflih, envoyé d'al-Nāṣir Aḥmad, souverain du Yémen, repartit pour son pays, accompagné de l'émir Baktamur al-Sa'dī, avec une lettre du sultan et son présent. La piété de ce Mufliḥ s'était répandue, ainsi que ses prières, ses aumônes et son comportement digne de louanges. Il avait eu besoin, en raison de ses nombreuses dépenses, d'emprunter de l'argent (qirọ al-māl).

e) Chronique anonyme, op. cit. amb. XXI-b, p. 186.

Le qādị̄ Amīn al-Dīn Muflih al-Turkī arriva d'Égypte avec un présent précieux (al-hadiyya al-făkhira). Un groupe de marchands vint avec lui à la noble cour à Ta'izz la bien gardée, le 22 dhū al-qa'da 820/31 déc. 1417. 


\section{Ambassade de 822/1419}

[Le 13 muharram 822/9 févr. 1419,] al-Maqrīzī note l'arrivée de l'émir Baktamur al-Sa'dī revenant du Yémen avec une lettre d'al-Nāșir Aḥmad b. al-Ashraf (Kitāb al-sulūk..., op. cit. n. 6, IV, 1, p. 479).

\section{Ambassade de 829/1426}

AL-MAQRīZĪ, Kitāb al-sulūk..., op. cit. n. 6, IV, 2, p. 715.

[Durant le mois de rabī' I 829/janv. 1426,] l'émir Urunbughā partit en mer vers La Mecque. Il avait avec lui le présent pour le maître du Yémen. Il s'y rendit par mer depuis Jidda, accompagné par un homme appelé Al-Ṭanbughā Franjī - qui avait gouverné Damiette plus d'une fois - et cinquante mamlūk sultaniens. Le sultan aurait félicité une personne qui aurait pris le Yémen avec ce nombre. Franjī s'attarda avec un navire sur le rivage de Halī b. Ya'qūb avec les Mamlūks. Aranbughā et cinq personnages partirent avec le cadeau et la lettre qui contenait une demande d'argent, en soutien pour la guerre sainte contre les Francs. Le souverain du Yémen entreprit d'expédier le présent, mais il apprit que Franjī avait pillé certains terroirs et tué quatre personnes. Le maître du Yémen condamna leur comportement, les admonesta et dit à Aranbughā : "Que cette nouvelle est bonne ! Il est de coutume qu'une seule personne vienne avec la lettre, mais vous êtes venus avec cinquante homme, et seul toi et cinq autres se sont présentés, le reste s'étant attardé. Et ils ont tué cinq de mes hommes. » Il le chassa sans avoir dépêché de présent et sans lui avoir rien remis. Lui et ceux qui étaient avec lui s'en repartirent avec leur propres moyens. Ils revinrent tous à La Mecque, et Aranbughā partit en cachette. 